\title{
Det er det, de unge vil have. En analyse af studerendes præferencer i relation til undervisning
}

Yosef Bhatti, seniorforsker, KORA - Det Nationale Institut for Kommuners og Regioners Analyse og Forskning.

Caroline Howard Grøn, adjunkt, Institut for Statskundskab, Københavns Universitet.

\section{Reviewet artikel}

Artiklen undersøger de studerendes forventninger til undervisere og undervisning gennem et survey af ca. 200 grunduddannelses- og overbygningsstuderende og finder, at der er stærkere præferencer for underviserens forelæsning og gennemgang af pensum i forhold til mere inddragende og perspektiverende undervisning. Ligeledes undersøges demografiske, strukturelle samt subjektive karakteristikas evne til at forklare variationer $i$ de studerendes præferencer. Mod forventning finder vi, at de studerendes præferencer til underviser og undervisning kun i meget ringe grad kan forklares ved de undersøgte faktorer ${ }^{1}$.

\section{Hvad er god undervisning?}

Umiddelbart er det et spørgsmål, der kan generere lige så mange svar, som der er studerende og undervisere. Men samtidig er der undervisere, der over tid opbygger et godt eller dårligt rygte blandt de studerende, og det forekommer heller ikke helt urimeligt at antage med basis i den universitetspædagogiske litteratur ( $\mathrm{fx}$ Biggs og Tang, 2007; Ramsden, 2003), at nogle former for undervisning og nogle typer af undervisere er bedre end andre.

Ofte bliver man som underviser konfronteret med anonyme skriftlige evalueringer med en tvivlsom svarprocent, eller mundtlige evalueringer, hvor det kun er en del af de studerende, der bidrager til vurderingen af undervisningsforløbet. Formålet med denne undersøgelse er at afdække studerendes syn på god undervisning lidt mere systematisk end den viden, som 'hear say' kan bidrage med eller de erfaringer, man som enkelt underviser kan opsamle gennem evalueringer. Mere konkret vil vi igennem en kvantitativ undersøgelse forsøge at afdække, hvilken type undervisning stu-

\footnotetext{
${ }^{1}$ Forfatterne vil gerne takke Jacob Gerner Hariri, Nicolai Kaarsen, Peter Thisted Dinesen, Thomas Harboe, redaktør Sidsel Winther samt to anonyme reviewere for konstruktive kommentarer og forslag. Vi skylder også en stor tak til Hanne Kraak, tidligere studievejleder på Institut for Statskundskab, der pilottestede vores undersøgelse samt Mie Lindgreen for grundig og effektiv hjælp til indtastning af spørgeskemaerne. Eventuelle fejl og mangler er alene forfatternes ansvar.
} 
derende efterspørger - herunder hvilke karakteristika ved underviserne, de lægger mest vægt på. Vi vil efterfølgende undersøge, om der er systematisk variation i de studerendes præferencer. Dermed ikke antaget, at studerende altid er eksperterne i, hvilken type undervisning, der skaber de bedste rammer for læring. Men det forekommer dog rimeligt at inddrage studerendes forståelse af, hvad der er god undervisning i den generelle planlægning og udvikling af undervisningsaktiviteter.

\section{Hvad efterspørges og hvem efterspørger hvad?}

Vi er interesserede $\mathrm{i}$ at undersøge de studerendes holdninger til to aspekter af god undervisning: 1) undervisers karakteristika og 2) de aktiviteter, der foregår i selve undervisningssituationen. Vi afgrænser os til at spørge ind til holdundervisning (som på undersøgelsesinstitutionen, Institut for Statskundskab, Københavns Universitet, vil sige undervisning på hold af 20-40 studerende), da forventningerne til undervisningen kan være forskellig afhængig af hvilken undervisningssituation, der er tale om.

Hvilke forventninger kunne man have til de studerendes ønsker? Helt overordnet skelnes der ofte i litteraturen mellem dyb og overfladisk læring (jf. Marton \& Säljö, 1976; Ramsden, 2003). Overfladisk læring er kendetegnet ved et grundlæggende ønske om at 'bestå eksamen'. Studerende vil derfor fokusere på en overfladisk forståelse af stoffet, fx udenadslære, og vil i mindre grad være i stand til at danne sig overblik eller anvende stoffet analytisk eller diskuterende. Dybdelæring er derimod kendetegnet ved at være drevet af et ønske om at forstå stoffet. Studerende med denne læringsform vil arbejde med at forstå, hvad der er væsentligst, forsøge at danne sig et samlet overblik, relatere stoffet til deres eksisterende referenceramme og anvende det analytisk og kritisk (Ramsden, 2003, s. 47). De to læringsformer fordrer forskellige typer af undervisning. Særligt fordrer dybdelæring et miljø med inddragelse og mulighed for kritisk stillingtagen. I deres undersøgelse af danske universiteter finder Lassesen og Jensen (2011a og 2011b), at undervisningsstilen spiller en væsentlig rolle for de studerendes læringsprofil. De finder, at små seminarer fordrer dybdelæring, mens forelæsninger fordrer overfladisk læring. På den baggrund har vi derfor en umiddelbar forventning om, at finde mange indikationer på dybdelæring, når vi spørger ind til de studerendes ønsker til holdundervisningen, der jo netop foregår i mindre enheder. Imidlertid må det være et empirisk spørgsmål, om den sammenhæng Lassesen og Jensen finder, også kan genfindes i den kontekst, vi undersøger. Den bredere litteratur gør i hvert fald en del ud af at understrege, at også forelæsningsbaseret undervisning kan planlægges på en måde, så den fremmer dybdelæring, ligesom undervisning på små hold kan organiseres på en måde, så der netop ikke skabes plads til at opbygge analytiske og kritiske kompetencer. Vores udgangspunkt er, at holdundervisning alt andet lige er et undervisningsformat, der gør det nemmere at skabe dybdelæring, men at hvorvidt dette faktisk sker, selvfølgelig er afhængigt af, hvordan aktørerne udfylder læringsrummet. 
Begreberne overflade- og dybdelæring kan problematiseres, ikke mindst når de fremstilles som værende hhv. en "god" og "dårlig" form for læring. Oftest vil der være en funktionel arbejdsdeling mellem forskellige former for læring, som man fx ser i læringstaksonomier (fx Bloom, Hastings \& Madaus, 1971). Empirisk kan man tilsvarende fremhæve, jf. argumentet ovenfor, at både studerende og undervisningssituationer kan variere over tid i graden af hhv. overflade- og dybdelæring. Vi vælger imidlertid at anvende de to begreber som overordnede analytiske konstruktioner, der kan hjælpe os til skabe et testbart analytisk set-up. Som antydet ovenfor finder vi det interessant, hvad de studerende generelt ønsker. Det er samtidig også interessant, om der er forskel på, hvilken type undervisning studerende efterspørger. Er der stor heterogenitet, er det som underviser svært at tilfredsstille alle ønsker samtidigt. Vi finder det særligt relevant at vide, om der er grupper, man særligt tilgodeser - eller omvendt risikerer at støde fra sig - hvis man lægger vægt på nogle former for undervisning frem for andre.

Hvilke forskelle kan vi på baggrund af litteraturen forvente af finde? Med udgangspunkt i både dansk og international litteratur vil vi gøre os en række overvejelser omkring, hvilke karakteristika der kan forventes at afgøre hvilken type undervisning, den studerende foretrækker.

Vi forventer, at en række demografiske variable vil spille ind i de studerendes ønsker til undervisningen. Lassesen \& Jensen (2011a og 2011b) viser i deres studier, at kvinder er mere tilbøjelige til dybdelæring end mænd, ligesom ældre studerende er mere tilbøjelige til dybdelæring end yngre studerende. Vi spørger derfor til både køn og længde af studier. Thomsen viser i sin analyse af studiemiljøet på Institut for Statskundskab, at undervisningen er kendetegnet ved en ret høj grad af indforståethed (Thomsen, 2012). Vi vælger derfor også at inddrage forældrenes sociale baggrund. Vi vender tilbage til de statskundskabsstuderendes karakteristika i næste afsnit.

På baggrund af Brophys (2010) diskussion af begrebet self-efficacy, der defineres som "beliefs in one's capabilities to organize and execute the courses of action required to produce given attainnments" (Bandura, 1997, s. 3, citeret hos Brophy, 2010, s. 51), opstiller vi endvidere to variable, vi mener kan have indflydelse på, hvilken type undervisning, der efterspørges. Brophy argumenterer for, at studerende med et højt niveau af self-efficacy er mere villige til at tage risici, og er mindre fokuserede på at udgå fejl end studerende med et lav niveau af self-efficacy. Det betyder grundlæggende, at studerende med højt niveau af self-efficacy vil være mere villige til at deltage i undervisningssituationer, der er præget af dybdelæring (jf. Ramsden, 2003) end studerende med lav self-efficacy. Det kunne fx komme til udtryk i, at studerende med høj self-efficacy i højere grad efterspørger inddragelse i undervisningen end gennemgang af pensum. Brophy anbefaler, at "as a teacher, help your students learn to 
attribute their successes to the combination of sufficient ability and reasonable effort, and to attribute their failures to (temporary) lack of information or response strategies (or to lack of effort, where this has been the case)" (Brophy, 2010, s. 50, original kursivering). Det henleder vores opmærksomhed på to aspekter af self-efficacy. For det første, troen på egne evner og for det andet troen på, at man yder en seriøs indsats. Vi vælger derfor at spørge de studerende til deres vurdering af eget niveau samt deres vurdering af egen indsats.

Endelig har en del statskundskabsstuderende omfattende studiearbejde ved siden af studierne. Vi vælger derfor også at inkludere omfanget af studiearbejde ud fra den hypotese, at meget omfattende studiearbejde alt andet lige vil gøre, at man vil være mindre tilbøjelig til at bruge ekstra tid på dyb læring. Figur 1 sammenfatter de faktorer, der teoretisk kunne forklare variationer i præferencer for underviser- samt undervisningskarakteristika.

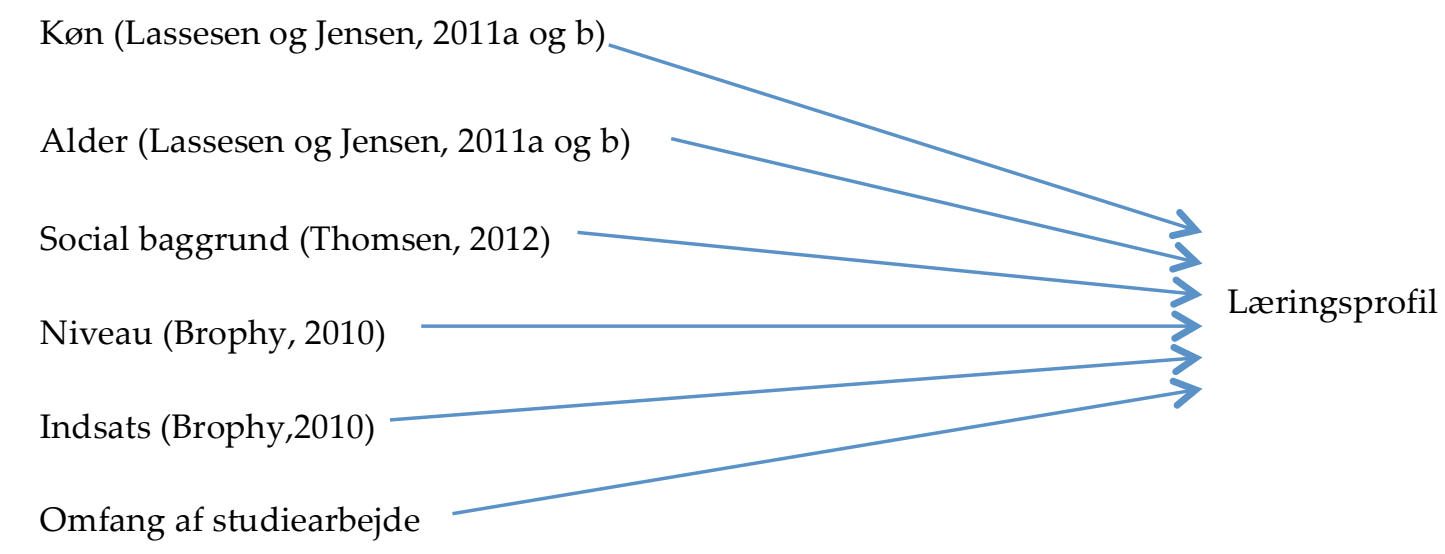

Figur 1: Faktorer der kan forventes at påvirke variationer i læringsprofil.

\section{Design og operationalisering}

Vi bruger et survey med lukkede spørgsmål til at spørge ind til de studerendes præferencer. For ikke at bebyrde de studerende unødigt og tage for meget tid fra undervisningen var spørgeskemaet relativt kort. Det bestod af 12 spørgsmål, der var vist på ét dobbeltsidet A4 ark. Spørgeskemaet er vedlagt som bilag 1.

Surveyet blev delt ud i forbindelse med undervisningen i forbindelse med en fællesforelæsning på andet semester, i forbindelse med BA-vejledningen (6. semester) på et hold samt i forbindelse med undervisningen på to overbygningshold. Alle hold var fra Institut for Statskundskab, Københavns Universitet. I de tre sidstnævnte tilfælde blev de studerende bedt om at udfylde spørgeskemaet i undervisningen, hvilket sikrede, at alle eller stort set alle, der var mødt op til undervisningen, svarede. I forbindelse med fællesforelæsningen var dette ikke muligt, hvorfor de studerende blev bedt om at besvare spørgeskemaet i pausen og aflevere det efter undervisningen, hvilket betød, at det var svært at sikre, at alle svarede. Ud af 246 tilmeldte til kurset 
fik vi svar fra 137 eller $56 \%$ (svarprocenten blandt dem, der var til forelæsningen, var sandsynligvis noget højere, da ikke alle 246 nødvendigvis følger faget i praksis, ligesom ikke alle møder op til samtlige forelæsninger). Samlet set fik vi svar fra 210 studerende - herunder 137 på 2. semester, 18 BA-projektskrivere og 55 studerende fra overbygningen.

Lad os først se på operationaliseringen af de afhængige variable. Vi ser som nævnt på to hovedaspekter af god undervisning: 1) undervisers karakteristika og 2) de aktiviteter, der foregår i selve undervisningssituationen.

Vores hypoteser tager udgangspunkt i litteraturen om dyb versus overfladisk læring. Men i stedet for at anvende det (omfattende) spørgeskema, der normalt anvendes til at afdække læringsprofilen (se fx Lassesen og Jensen, 2011a og b for en dansk oversættelse), anvender vi en mere praksisnær operationalisering af de afhængige variable. Det gør vi, fordi vi ikke er så interesserede i, hvilken form for læring de studerende anvender, men i stedet er interesserede i, hvilken type af læringsmiljø de ønsker at befinde sig i. Derudover har vi valgt, delvist på baggrund af litteraturen og delvist på baggrund at en pilottest af kategorierne, at formulere de mulige kategorier i det endelige spørgeskema så tæt på de studerendes hverdagssprog som muligt. Konkret betyder det, at vi operationaliserer underviseres karakteristika i følgende kategorier:2

- God formidlingsevne

- Tilgængelighed, fx villig til at svare på spørgsmål udenfor undervisningstiden

- Engagement

- Velstruktureret

- Kendskab til pensum/fagligt overblik

- Venlig/sympatisk

- Inddragende omkring undervisningens indhold og struktur

Med udgangspunkt $\mathrm{i}$ litteraturen om dyb versus overfladisk læring vil vi forvente, at studerende, der er mest interesserede i dyb læring vil prioritere tilgængelighed, kendskab til pensum og inddragende relativt højere end studerende, der primært orientere sig mod overfladisk læring. Det kunne fx gøre sig gældende for studerende, der er relativt langt på uddannelsen, der vurderer deres eget faglige niveau relativt højt, og som synes, de yder en stor indsats i forhold til faget. I den konkrete operationalisering bliver deltagerne i vores survey bedt om at prioriterer mellem de 7 kategorier.

\footnotetext{
${ }^{2}$ Man kunne kritisk overveje, om kategorien 'formidlingsevne' rettelig skal ses som en nødvendig betingelse for, at de øvrige underviserkarakteristika er nyttige for de studerende, og det derfor nærmere er en overkategori til de øvrige end en kategori på linje med dem. Vores empiriske resultater understreger, at dette kunne være en mulig tolkning.
} 
I forhold til undervisningssituationen blev de studerende bedt om at prioritere mellem følgende elementer i undervisningen:

- Gruppearbejde og efterfølgende diskussion

- Studenteroplæg og efterfølgende diskussion

- Inddragelse af praktikere, fx oplæg og efterfølgende diskussion

- Forelæsning/undervisers gennemgang

Kategorierne er udvalgt, så de repræsenterer de typiske elementer i holdundervisning på Institut for Statskundskab. Vi vil forvente, at de studerende, der foretrækker dyb læring, vil foretrække de undervisningsformer, der faciliteter sådan en læring fx gruppearbejde og diskussion samt studenteroplæg og diskussion, hvorimod forelæsning/undervisers gennemgang lægger mere op til overfladisk læring. Som et ekstra perspektiv på indholdet af undervisers gennemgang spørger vi endvidere, om de studerende synes, det er vigtigst, at underviser gennemgår pensum eller perspektiverer det.

De uafhængige variable er køn, alder (fødselsår, omregnet til alder), årstal for påbegyndelse af seneste BA (omregnet til anciennitet på studiet i år), selvvurdering af arbejdsindsats på studiet (5 kategorier fra meget lav til meget høj), selvvurdering af eget faglige niveau (5 kategorier fra den dårligste femtedel på årgang til den bedste femtedel på årgang), ugentlig lønnede studiearbejde (5 kategorier fra højst 5 timer til mere end 20 timer) samt mors og fars højest gennemførte uddannelse (6 kategorier fra grundskole til lang videregående). De præcise spørgsmålsformuleringer fremgår af spørgeskemaet, der er vedlagt som bilag.

\section{Stud.scient.pol.er - hvad kendetegner dem?}

Inden vi går til selve analysen, skal det naturligvis nævnes, at det er klart, at ikke alle studerende er som de studerende, vi har undersøgt. Alle vores respondenter er statskundskabsstuderende. De er kendetegnet ved at have et meget højt karaktergennemsnit (10,9 i 2012 jf. KOT) i deres adgangsgivende eksamen. I en komparativ undersøgelse af studerende på Litteraturvidenskab, International Business Communication og Statskundskab viser Thomsen (2012) nogle af de parametre, hvor statskundskabsstuderende adskiller sig fra andre typer af studerende. Først og fremmest rekrutterer Statskundskab fra akademikerhjem, ikke kun sammenlignet med de to ovennævnte studier, men også mere generelt sammenlignet med andre universitetsuddannelser (Thomsen, 2012, s. 570-571). Sammenlignet med Litteraturvidenskab, der også rekrutterer fra hjem med lang uddannelse, har statskundskabsstuderende ofte forældre, der arbejder som konsulenter, embedsmænd eller ledere. Statskundskabsstuderende kommer også ofte fra hjem, hvor der bliver læst avis og diskuteret politik (Thomsen, 2012, s. 575). 
Statskundskabsstuderende tager en uddannelse, der retter sig mod administrative generalistarbejdsopgaver. Thomsen fremhæver, at statskundskabsstuderende anser studiet som en sikker vej til et godt job, men at de har valgt studiet på grund af en grundlæggende interesse for samfundsforhold (Thomsen, 2012, s. 577). Dette karakteristikum kan også påvirke generaliserbarheden af vores undersøgelse. Endelig er det værd at overveje, om kulturen på Statskundskab kan spille en rolle. Thomsen beskriver i sin artikel, hvordan statskundskabsstuderende beskriver sig selv som "ambitious, self-confident, multi-talented and entrepeneurial" (Thomsen, 2010, s. $579)$.

Det er klart, at statskundskabsstunderende adskiller sig fra andre grupper af studerende. Det er ikke muligt for os at vide præcist, hvad de karakteristika, vi diskuterede ovenfor, betyder (fx kunne det høje snit fra adgangsgivende eksamener på den ene indikere overskud til dybdelæring, men kunne på den anden side også være udtryk for, at de studerende primært er karakter- og eksamensfokuserede). Men det, der er vores primære interesse, er at afdække systematiske variationer inden for populationen. I det omfang andre skulle have interesse i at overføre vores resultater på andre studentergrupper, er det selvfølgelig værd at overveje, om det er kulturelle eller andre faktorer, der gør, at det bliver svært at sammenligne.

\section{Analyse}

Hvad prioriterer de studerende?

Vi starter med at analysere de studerendes generelle prioriteringer. Tabel 1 opsummerer resultaterne. (1)-(7) angiver den gennemsnitlige prioritering af underviseres karakteristika på de 7 dimensioner. (8)-(11) angiver de gennemsnitlige prioriteringer af undervisningsformer på de 4 dimensioner, mens (12) angiver andelen, der prioriterer perspektiverende undervisning i stedet for pensumgennemgang. For at lette tolkningen har vi i alle tilfælde rekodet variablene til at skalere fra 0 til 1, således at 1 angiver, at man har givet et karakteristikum den højest mulige prioritering, mens 0 angiver den lavest mulige værdi. Dvs., hvis vi ser på (1)-(7), hvor der er 7 mulige prioriteringer, tildeles en førsteprioritet værdien 1, andenprioriteten værdien 5/6, tredjeprioriteten $4 / 6$ og så fremdeles, hvorved syvendeprioriteten får værdien 0 . Tilsvarende er de mulige værdier i (8)-(11) med 4 mulige prioriteringer 1, 2/3, 1/3, 0 , mens man i (12) får værdien 1 , hvis man har prioriteret perspektivering og ellers 0 . 


\begin{tabular}{|c|c|c|c|c|c|c|c|}
\hline & $\begin{array}{c}(1) \\
\text { Formid- } \\
\text { ling }\end{array}$ & $\begin{array}{c}\text { (2) } \\
\text { Tilgænge- } \\
\text { lighed }\end{array}$ & $\begin{array}{c}(3) \\
\text { Engage- } \\
\text { ment }\end{array}$ & $\begin{array}{c}(4) \\
\text { Velstruktu- } \\
\text { reret }\end{array}$ & $\begin{array}{c}(5) \\
\text { Fagligt } \\
\text { overblik }\end{array}$ & $\begin{array}{c}\text { (6) } \\
\text { Venlig }\end{array}$ & $\begin{array}{c}(7) \\
\text { Inddra- } \\
\text { gende }\end{array}$ \\
\hline Gennemsnit & $\begin{array}{c}0.91 \\
(0.011) \\
\end{array}$ & $\begin{array}{c}0.22 \\
(0.018) \\
\end{array}$ & $\begin{array}{c}0.63 \\
(0.017) \\
\end{array}$ & $\begin{array}{c}0.67 \\
(0.015) \\
\end{array}$ & $\begin{array}{c}0.65 \\
(0.017) \\
\end{array}$ & $\begin{array}{c}0.28 \\
(0.016) \\
\end{array}$ & $\begin{array}{c}0.24 \\
(0.019) \\
\end{array}$ \\
\hline & $\begin{array}{c}(8) \\
\text { Gruppe- } \\
\text { arbejde }\end{array}$ & $\begin{array}{c}\text { (9) } \\
\text { Studen- } \\
\text { teroplæg }\end{array}$ & $\begin{array}{c}(10) \\
\text { Praktike- } \\
\text { re }\end{array}$ & $\begin{array}{c}\text { (11) } \\
\text { Forelæs- } \\
\text { ning }\end{array}$ & $\begin{array}{c}\text { (12) } \\
\text { Perspek- } \\
\text { tivering }\end{array}$ & & \\
\hline Gennemsnit & $\begin{array}{c}0.41 \\
(0.020) \\
\end{array}$ & $\begin{array}{c}0.17 \\
(0.016) \\
\end{array}$ & $\begin{array}{c}0.54 \\
(0.021) \\
\end{array}$ & $\begin{array}{c}0.90 \\
(0.016) \\
\end{array}$ & $\begin{array}{r}0.33 \\
(0.03) \\
\end{array}$ & & \\
\hline
\end{tabular}

Standardfejl i parenteser. For alle prioriteringer går skalaen fra 0 (sidsteprioritet) til 1 (førsteprioritet). Jo højere værdier, desto højere prioritering.

Tabel 1: Gennemsnitsprioritering for hoer karakteristikum.

I prioriteringen af underviserens karakteristika kommer formidlingsevne på en klar førsteplads. Hele $65 \%$ af respondenterne har prioriteret egenskaben på en førsteplads og yderligere $21 \%$ på en andenplads af de syv egenskaber, hvilket giver en gennemsnitsscore på hele 0.91 (hvor 1 altså svarer til, at alle respondenter havde givet egenskaben førsteprioritet og 0 svarer til, at alle havde givet den sidsteproritet). Et midterfelt dannes af egenskaberne velstruktureret, fagligt overblik og engagement, mens egenskaber som venlighed, inddragende og tilgængelighed vægtes lavt.

I prioriteringen af undervisningsformer findes også en klar førsteprioritet i form af forelæsning. Hele $82 \%$ har denne undervisningstype som førsteprioritet. Mere inddragende undervisningsformer såsom gruppearbejde og studenteroplæg gives lav prioritet. I (12) ser vi endvidere, at kun omkring en tredjedel lægger mest vægt på, at underviseren perspektiverer og går ud over pensum, mens to tredjedele finder det vigtigst, at underviser gennemgår pensum. Der synes altså at være en generel tendens til, at de mere passive og mindre krævende former for undervisning opprioriteres. Det er måske en smule overraskende givet studentersammensætningen på Statskundskab, der som nævnt i sidste afsnit består af relativt ambitiøse studerende med et højt adgangssnit, men det kan som tidligere antydet måske skyldes, at de studerende er meget eksamensfokuserede.

\section{Hvem prioriterer hoad?}

Overordnet set så vi altså, at de studerende prioriterede forelæsning og gennemgang af pensum, selvom vi spurgte ind til holdundervisning på mindre til mellemstore hold (20-40 studerende). Vi undersøger nu, om bestemte typer af studerende har bestemte ønsker til underviser og undervisning. Som tidligere nævnt kunne man fx forestille sig forskelle på tværs af køn, alder, studieanciennitet mv. For at lette tolkningen er alle disse variable - som de afhængige variable - rekodet til at skalere fra 0 til 1, hvor 1 er den højeste observerede værdi, mens 0 er den laveste. Deskriptiv statistik for variablene kan ses i artiklens bilag 2 . 
Vi undersøger variationer i prioriteter ved hjælp af en separat ordinary least squares (OLS)-model for hver prioritering (i model 24, tabel 2 og model 36, tabel 3 er resultaterne substantielt de samme med en logistisk regressionsmodel). En OLS-model er basalt set en multivariat statistisk model, der kan anvendes til at estimere den separate/individuelle effekt af forskellige variable. I tabel 2 starter vi med at forklare prioriteringerne ved hjælp af de demografiske og strukturelle variable (køn, alder, studieanciennitet, mors uddannelse og fars uddannelse), mens vi først inkluderer de subjektive variable (selvvurderet arbejdsindsats og selvvurderet fagligt niveau) samt studiearbejde i tabel 3. Dette sker ud fra en betragtning over variablenes placering i den kausale kæde, hvor de demografiske/strukturelle variable må komme først i tidsfølgen. En positiv koefficient angiver, at den uafhængige variabel øger den studerendes prioritering af det givne karakteristikum/undervisningsform, mens en negativ koefficient betyder, at man prioriterer det mindre, når værdien på den uafhængige variabel stiger.

\begin{tabular}{lccccccc}
\hline & $\begin{array}{c}(13) \\
\text { Formid- } \\
\text { ling }\end{array}$ & $\begin{array}{c}(14) \\
\text { Tilgænge- } \\
\text { lighed }\end{array}$ & $\begin{array}{c}(15) \\
\text { Engage- } \\
\text { ment }\end{array}$ & $\begin{array}{c}(16) \\
\text { Velstruk- } \\
\text { tureret }\end{array}$ & $\begin{array}{c}(17) \\
\text { Fagligt } \\
\text { overblik }\end{array}$ & $\begin{array}{c}(18) \\
\text { Venlig }\end{array}$ & $\begin{array}{c}(19) \\
\text { Inddra- } \\
\text { gende }\end{array}$ \\
\hline Kvinde & -0.016 & 0.044 & -0.069 & 0.024 & -0.0038 & $-0.067^{*}$ & 0.011 \\
& $(0.022)$ & $(0.035)$ & $(0.036)$ & $(0.032)$ & $(0.035)$ & $(0.033)$ & $(0.038)$ \\
Alder & 0.14 & $0.58^{* * *}$ & 0.20 & 0.25 & 0.093 & $0.32^{*}$ & $0.65^{* * *}$ \\
& $(0.10)$ & $(0.16)$ & $(0.16)$ & $(0.15)$ & $(0.16)$ & $(0.15)$ & $(0.17)$ \\
Studieanc. & -0.071 & -0.071 & -0.15 & -0.056 & -0.10 & 0.029 & $-0.22^{*}$ \\
& $(0.060)$ & $(0.096)$ & $(0.097)$ & $(0.087)$ & $(0.097)$ & $(0.091)$ & $(0.10)$ \\
Mors udd. & -0.0058 & 0.076 & 0.0015 & -0.018 & 0.10 & -0.092 & -0.020 \\
& $(0.046)$ & $(0.075)$ & $(0.075)$ & $(0.066)$ & $(0.074)$ & $(0.070)$ & $(0.079)$ \\
Fars udd. & 0.017 & 0.058 & 0.014 & -0.037 & -0.056 & 0.072 & 0.012 \\
& $(0.040)$ & $(0.067)$ & $(0.067)$ & $(0.057)$ & $(0.066)$ & $(0.063)$ & $(0.069)$ \\
Konstant & $0.91^{* * *}$ & 0.046 & $0.67^{* * *}$ & $0.68^{* * *}$ & $0.63^{* * *}$ & $0.29^{* * *}$ & $0.22^{* *}$ \\
& $(0.042)$ & $(0.069)$ & $(0.069)$ & $(0.060)$ & $(0.067)$ & $(0.065)$ & $(0.074)$ \\
\hline N & 196 & 181 & 188 & 190 & 186 & 182 & 180 \\
R-squared & 0.015 & 0.089 & 0.031 & 0.028 & 0.015 & 0.069 & 0.083 \\
F-statistik & 0.56 & 3.42 & 1.18 & 1.05 & 0.54 & 2.59 & 3.14 \\
RMSE & 0.15 & 0.24 & 0.24 & 0.21 & 0.24 & 0.22 & 0.25 \\
\hline
\end{tabular}




\begin{tabular}{lcccc|c}
\hline & $\begin{array}{c}(20) \\
\text { Gruppe- } \\
\text { arbejde }\end{array}$ & $\begin{array}{c}(21) \\
\text { Studenter- } \\
\text { oplæg }\end{array}$ & $\begin{array}{c}(22) \\
\text { Praktikere }\end{array}$ & $\begin{array}{c}(23) \\
\text { Forelæsning }\end{array}$ & $\begin{array}{c}(24) \\
\text { Perspek- } \\
\text { tivering }\end{array}$ \\
\hline Kvinde & 0.036 & -0.052 & -0.072 & $0.070^{*}$ & -0.012 \\
Alder & $(0.041)$ & $(0.033)$ & $(0.043)$ & $(0.033)$ & $(0.068)$ \\
& 0.066 & $0.35^{*}$ & 0.34 & -0.13 & 0.39 \\
Studieanc. & $(0.19)$ & $(0.15)$ & $(0.20)$ & $(0.16)$ & $(0.32)$ \\
& -0.00075 & $-0.27^{* *}$ & -0.025 & 0.11 & -0.065 \\
Mors udd. & $(0.11)$ & $(0.091)$ & $(0.12)$ & $(0.092)$ & $(0.19)$ \\
& -0.11 & 0.047 & 0.12 & -0.034 & 0.12 \\
Fars udd. & $(0.086)$ & $(0.070)$ & $(0.091)$ & $(0.071)$ & $(0.14)$ \\
& 0.11 & 0.10 & -0.10 & -0.074 & 0.059 \\
Konstant & $(0.076)$ & $(0.062)$ & $(0.081)$ & $(0.063)$ & $(0.12)$ \\
& $0.39^{* * * *}$ & 0.11 & $0.54^{* * *}$ & $0.94^{* * *}$ & 0.16 \\
N & $(0.078)$ & $(0.064)$ & $(0.084)$ & $(0.064)$ & $(0.13)$ \\
R-squared & 191 & 190 & 193 & 196 & 197 \\
F-statistik & 0.018 & 0.079 & 0.044 & 0.039 & 0.014 \\
RMSE & 0.68 & 3.17 & 1.74 & 1.55 & 0.54 \\
\hline
\end{tabular}

Standardfejl i parenteser. ${ }^{*} p<0.05,{ }^{* *} p<0.01,{ }^{* * *} p<0.001$.

Tabel 2: Forklaring af høj prioritering af forskellige afhængige variable ud fra objektive variable.

Det der springer i øjnene i Tabel 2 er, at der stort set ingen sammenhæng er mellem de demografiske karakteristika og prioriteringer af undervisningen. ${ }^{3}$ Vores $\mathrm{R}$ squared værdier er flere steder tæt på 0, og der synes at være få systematiske sammenhænge. Der er en svag tendens til, at ældre studerende prioriterer inddragelse lidt mere end andre, hvilket er i overensstemmelse med vores forventninger fra Lassesen \& Jensen (2011a; 2011b), men disse resultater er noget sensitive overfor outliers (dvs. resultaterne afhænger af nogle få cases). Den lave prioritering af studenteroplæg synes at være lidt mere udpræget blandt dem, der er nået langt på studiet, mens kvinderne lægger lidt mere vægt på forelæsning og mindre på venlighed end mændene. Vægten på forelæsning går umiddelbart mod vores forventning om, at kvinderne vil prioritere inddragende undervisningsformer højere.

I Tabel 3 inkluderer vi de subjektive variable (selvvurderet arbejdsindsats og selvvurderet fagligt niveau) og studiearbejde. Det tillader os til dels at se, om de få sammenhænge, vi har fundet, virker gennem (bliver medieret af) disse variable og dels, om de har nogen selvstændig effekt, når der tages højde for de subjektive variable.

\footnotetext{
${ }^{3}$ Det skal bemærkes, at der på formidlingsvariablen er ringe varians at forklare, da stort set alle prioriterer den højt, men der findes lav forklaringskraft for stort set alle de anvendte afhængige variable - også dem, hvor der er store forskelle i prioriteringerne respondenterne imellem.
} 


\begin{tabular}{lccccccc}
\hline & $\begin{array}{c}(25) \\
\text { Formid- } \\
\text { ling }\end{array}$ & $\begin{array}{c}\text { Tilgænge- } \\
\text { lighed }\end{array}$ & $\begin{array}{c}(27) \\
\text { Engage- } \\
\text { ment }\end{array}$ & $\begin{array}{c}\text { (28) } \\
\text { Velstruk- } \\
\text { tureret }\end{array}$ & $\begin{array}{c}\text { Fagligt } \\
\text { overblik }\end{array}$ & $\begin{array}{c}(30) \\
\text { Venlig }\end{array}$ & $\begin{array}{c}(31) \\
\text { Inddra- } \\
\text { gende }\end{array}$ \\
\hline Kvinde & -0.025 & 0.026 & $-0.080^{*}$ & 0.021 & 0.011 & -0.062 & 0.019 \\
& $(0.023)$ & $(0.037)$ & $(0.038)$ & $(0.033)$ & $(0.037)$ & $(0.036)$ & $(0.041)$ \\
Alder & 0.17 & $0.58^{* * *}$ & 0.19 & 0.23 & 0.090 & $0.33^{*}$ & $0.65^{* * *}$ \\
& $(0.10)$ & $(0.16)$ & $(0.17)$ & $(0.15)$ & $(0.16)$ & $(0.15)$ & $(0.18)$ \\
Studieanc. & -0.011 & -0.11 & $-0.23^{*}$ & -0.12 & -0.055 & 0.047 & -0.17 \\
& $(0.066)$ & $(0.11)$ & $(0.11)$ & $(0.096)$ & $(0.11)$ & $(0.10)$ & $(0.12)$ \\
Mors udd. & -0.013 & 0.091 & 0.014 & -0.037 & 0.100 & -0.086 & -0.022 \\
& $(0.046)$ & $(0.076)$ & $(0.077)$ & $(0.067)$ & $(0.076)$ & $(0.072)$ & $(0.082)$ \\
Fars udd. & 0.044 & 0.069 & 0.0046 & -0.038 & -0.075 & 0.062 & 0.025 \\
& $(0.040)$ & $(0.069)$ & $(0.070)$ & $(0.059)$ & $(0.069)$ & $(0.065)$ & $(0.072)$ \\
Selvv arb.indsats & 0.031 & $0.27^{* *}$ & 0.10 & 0.058 & -0.13 & -0.12 & -0.15 \\
& $(0.058)$ & $(0.096)$ & $(0.098)$ & $(0.086)$ & $(0.098)$ & $(0.092)$ & $(0.10)$ \\
Mængde studiearb. & -0.041 & 0.068 & 0.091 & $0.12^{*}$ & -0.074 & -0.065 & -0.090 \\
& $(0.039)$ & $(0.065)$ & $(0.066)$ & $(0.058)$ & $(0.066)$ & $(0.062)$ & $(0.071)$ \\
Selvv fagligt niv. & $-0.17^{* *}$ & -0.048 & 0.038 & -0.042 & 0.11 & 0.084 & -0.00078 \\
& $(0.055)$ & $(0.091)$ & $(0.092)$ & $(0.081)$ & $(0.092)$ & $(0.087)$ & $(0.100)$ \\
Konstant & $0.99^{* * *}$ & -0.14 & $0.57^{* * *}$ & $0.66^{* * *}$ & $0.67^{* * *}$ & $0.34^{* * *}$ & $0.33^{* *}$ \\
& $(0.060)$ & $(0.10)$ & $(0.10)$ & $(0.088)$ & $(0.100)$ & $(0.096)$ & $(0.11)$ \\
\hline N & 189 & 174 & 181 & 183 & 179 & 175 & 173 \\
R-squared & 0.077 & 0.14 & 0.056 & 0.054 & 0.030 & 0.090 & 0.10 \\
F-statistik & 1.88 & 3.24 & 1.28 & 1.23 & 0.66 & 2.05 & 2.36 \\
RMSE & 0.15 & 0.24 & 0.24 & 0.21 & 0.24 & 0.22 & 0.25 \\
\hline
\end{tabular}

\begin{tabular}{|c|c|c|c|c|c|}
\hline & $\begin{array}{c}(32) \\
\text { Gruppe- } \\
\text { arbejde }\end{array}$ & $\begin{array}{c}\text { (33) } \\
\text { Studenter- } \\
\text { oplæg }\end{array}$ & $\begin{array}{c}(34) \\
\text { Praktikere }\end{array}$ & $\begin{array}{c}\text { (35) } \\
\text { Forelæs- } \\
\text { ning }\end{array}$ & $\begin{array}{c}\text { (36) } \\
\text { Perspektive- } \\
\text { ring }\end{array}$ \\
\hline Kvinde & $\begin{array}{c}0.037 \\
(0.043)\end{array}$ & $\begin{array}{l}-0.038 \\
(0.035)\end{array}$ & $\begin{array}{l}-0.084 \\
(0.046)\end{array}$ & $\begin{array}{c}0.062 \\
(0.036)\end{array}$ & $\begin{array}{l}-0.015 \\
(0.070)\end{array}$ \\
\hline Alder & $\begin{array}{l}0.071 \\
(0.19)\end{array}$ & $\begin{array}{c}0.34^{*} \\
(0.15)\end{array}$ & $\begin{array}{c}0.34 \\
(0.20)\end{array}$ & $\begin{array}{l}-0.12 \\
(0.16)\end{array}$ & $\begin{array}{c}0.35 \\
(0.31)\end{array}$ \\
\hline Studieanc. & $\begin{array}{l}-0.024 \\
(0.12)\end{array}$ & $\begin{array}{l}-0.24^{*} \\
(0.10)\end{array}$ & $\begin{array}{r}-0.056 \\
(0.13)\end{array}$ & $\begin{array}{c}0.13 \\
(0.10)\end{array}$ & $\begin{array}{l}-0.19 \\
(0.20)\end{array}$ \\
\hline Mors udd. & $\begin{array}{c}-0.14 \\
(0.088)\end{array}$ & $\begin{array}{c}0.066 \\
(0.071)\end{array}$ & $\begin{array}{c}0.13 \\
(0.093)\end{array}$ & $\begin{array}{c}-0.041 \\
(0.074)\end{array}$ & $\begin{array}{c}0.18 \\
(0.14)\end{array}$ \\
\hline Fars udd. & $\begin{array}{c}0.14 \\
(0.079)\end{array}$ & $\begin{array}{c}0.079 \\
(0.064)\end{array}$ & $\begin{array}{c}-0.10 \\
(0.084)\end{array}$ & $\begin{array}{c}-0.067 \\
(0.065)\end{array}$ & $\begin{array}{c}-0.0021 \\
(0.12)\end{array}$ \\
\hline Selvv arb.indsats & $\begin{array}{c}-0.055 \\
(0.11)\end{array}$ & $\begin{array}{c}-0.021 \\
(0.091)\end{array}$ & $\begin{array}{l}-0.029 \\
(0.12)\end{array}$ & $\begin{array}{c}0.12 \\
(0.094)\end{array}$ & $\begin{array}{l}0.49^{* *} \\
(0.18)\end{array}$ \\
\hline Mængde studiearb. & $\begin{array}{c}0.045 \\
(0.074)\end{array}$ & $\begin{array}{l}-0.076 \\
(0.060)\end{array}$ & $\begin{array}{c}0.016 \\
(0.079)\end{array}$ & $\begin{array}{c}0.026 \\
(0.062)\end{array}$ & $\begin{array}{c}0.16 \\
(0.12)\end{array}$ \\
\hline Selvv fagligt niv. & $\begin{array}{c}-0.12 \\
(0.11)\end{array}$ & $\begin{array}{c}0.17^{*} \\
(0.085)\end{array}$ & $\begin{array}{c}-0.0019 \\
(0.11)\end{array}$ & $\begin{array}{c}-0.094 \\
(0.087)\end{array}$ & $\begin{array}{c}0.20 \\
(0.17)\end{array}$ \\
\hline Konstant & $\begin{array}{l}0.49^{* * *} \\
(0.11)\end{array}$ & $\begin{array}{c}0.035 \\
(0.095) \\
\end{array}$ & $\begin{array}{l}0.56^{* * *} \\
(0.12)\end{array}$ & $\begin{array}{l}0.90^{* * * *} \\
(0.096)\end{array}$ & $\begin{array}{l}-0.33 \\
(0.19) \\
\end{array}$ \\
\hline $\mathrm{N}$ & 184 & 183 & 186 & 189 & 191 \\
\hline R-squared & 0.035 & 0.11 & 0.051 & 0.058 & 0.087 \\
\hline F-statistik & 0.79 & 2.56 & 1.20 & 1.38 & 2.18 \\
\hline RMSE & 0.28 & 0.22 & 0.30 & 0.23 & 0.46 \\
\hline
\end{tabular}

Standardfejl i parenteser. ${ }^{*} p<0.05,{ }^{* *} p<0.01,{ }^{* * *} p<0.001$.

Tabel 3: Forklaring af høj prioritering af forskellige afhængige variable ud fra objektive og subjektive variable.

Inklusionen af de subjektive variable ændrer ikke billedet af, at det er svært at forklare forskellene i prioriteringer systematisk, selv om vi har inddraget nogle af de hyppigst anvendte variable i litteraturen. Det mest iøjefaldende er, at de, der efter egen 
vurdering arbejder hårdt, ønsker højere tilgængelighed fra underviserne, ligesom de prioriterer perspektivering noget højere end de øvrige. Særligt sidstnævnte giver god mening, da de ambitiøse, hvad angår arbejdsindsats, måske på forhånd har et stærkere kendskab til undervisningens tekster og således vil finde tekstgennemgang mindre anvendeligt. Hvis man selv mener at have højt fagligt niveau, lægger man desuden mindre vægt på formidling som en egenskab hos underviserne. Dette kan hænge sammen med, at de selvvurderede dygtige finder, at de har mere overskud til at fange indholdet, selv hvis formidlingen ikke er i top. Der er samlet set nogen tendens til, at de selvvurderet dygtige og hårdtarbejdende ønsker at blive inddraget og udfordret noget mere (jf. Brophy, 2010) om end, det kun kommer til udtryk i nogle få af modellerne.

\section{Konklusion}

I denne undersøgelse har vi set på, hvilke ønsker de studerende på Statskundskab har til underviser og undervisningen i forbindelse med holdundervisning på uddannelsen. Vi fandt en generel tendens til, at de studerende prioriterede elementer, der normalt associeres med lærerstyret undervisning og gennemgang af pensum. Dette er måske noget overraskende, da statskundskabsstuderende er karakteriseret ved høje adgangssnit (hvilket dog til dels kan skyldes stort eksamens- og karakterfokus) og tidligere er karakteriseret som værende studerende, der er drevet af en grundlæggende interesse i samfundet. Man kunne derfor umiddelbart forvente, at statskundskabsstuderende ville være mere interesserede i mere inddragende og perspektiverende undervisningsformer.

Særligt interessant er det, at selv om der selvfølgelig er nogen variation i de studerendes ønsker til underviser og undervisning, er denne stort set usystematisk i den forstand, at den hverken kan forklares ved hyppigt anvendte baggrundskarakteristika eller subjektive vurderinger. Dette er vigtigt i den forstand, at det viser, at man - i hvert fald i forbindelse med holdundervisningen på Statskundskab - ikke tilgodeser eller skuffer bestemte gruppers præferencer, når man vælger sin overordnede prioritering af undervisningsformer.

Kritisk kan man måske spørge, om skellet mellem dybdelæring og overfladelæring skal tages helt så bogstaveligt, som det gøres her. Kunne man forestille sig, at de generelt dygtige studerende, vi underviser på Statskundskab efterspørger pejlemærker i litteraturen (i form af pensumgennemgang), der kan facilitere den dybdelæring, de så selv, før og efter undervisningen, er ansvarlige for? Efter at have eksamineret en del af denne undersøgelses population er det i hvert fald klart, at dybdelæring finder sted, også selvom det ikke er det, flertallet af de studerende direkte efterspørger i undersøgelsen. 
På trods af dette forbehold mener vi, at vores undersøgelse bibringer relevant viden. Vi håber at kunne bidrage til at give underviserne et indtryk af, hvilke typer af undervisning de studerende foretrækker, og hvilke variationer (eller mangel på samme) der er mellem forskellige studentergrupper. Også selvom vi kun studerer en uddannelse og en type undervisning. Det betyder naturligvis ikke, at det er den type undervisning, vi som undervisere skal tilbyde men blot, at det, uanset hvilken undervisningsform man tilbyder, kan være værdifuldt at vide, hvilke typer af forventninger og ønsker der danner udgangspunktet hos de studerende.

Yosef Bhattis forskning fokuserer særligt på valgdeltagelse. Hans forskningsinteresse dækker desuden meningsmålinger, politisk repræsentation, offentlige reformer samt miljøpolitik. Hans forskning er bl.a. udgivet $i$ European Journal of Political Research, Public Choice, Electoral Studies, Public Administration og Governance.

Caroline Howard Grøn forsker $i$ offentlig ledelse og offentlige organisationer samt $i$ EuropaKommissionen, for øjeblikket særligt i relation til små lande. Hun har skrevet bøger om offentlig forvaltning og ledelse og har publiceret artikler $i$ bl.a. Review of Public Personnel Administration og Journal of European Integration. 


\section{Bilag 1: Spørgeskemaet}

Kære studerende! Vi håber, du vil svare på dette korte spørgeskema, som skal bruges til at undersøge de studerendes ønsker til undervisningen på statskundskab. Spørgsmålene vedrører holdundervisningen og altså ikke fællesforelæsninger. Vi håber, det kan hjælpe os med at forbedre undervisningskvaliteten på udannelsen. Spørgeskemaet besvares anonymt, og det vil ud fra afrapporteringen af resultaterne ikke være muligt at identificere enkeltbesvarelser.

1. Hvordan vil du prioritere følgende 7 egenskaber hos en holdunderviser - dvs., i forbindelse med undervisning på hold af ca. 40 studerende - på statskundskab? (angiv "1" ud fra den egenskab du mener er vigtigst, "2" ud fra den andenvigtigste, "3" ud fra den tredjevigtigste osv.)

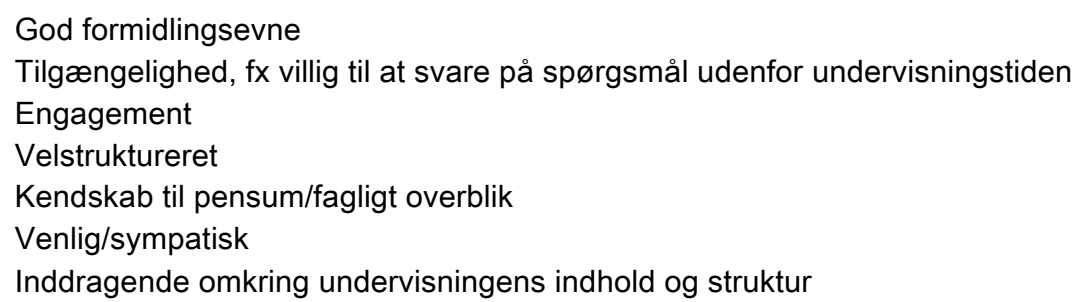

2. Hvordan vil du prioritere følgende 4 undervisningsformer $\mathrm{i}$ forbindelse med holdundervisning på statskundskab? (Skriv "1" ud fra det du mener bør fylde mest tidsmæssigt, "2" ud fra det der bør fylde andenmest osv.)

Gruppearbejde og efterfølgende diskussion

Studenteroplæg og efterfølgende diskussion

Inddragelse af praktikere, fx oplæg og efterfølgende diskussion

Forelæsning/undervisers gennemgang

\section{Hvilken af følgende ting finder du vigtigst i forbindelse med holdundervisning på statskundskab? (sæt kun ét kryds) \\ - Holdunderviseren gennemgår pensum \\ - Holdunderviseren perspektiverer pensum/går ud over pensum}
4. Hvad er dit køn?
- Kvinde
a Mand

5. Hvilket år er du født? (fx"1982")

6. Hvornår påbegyndte du dit studie? (angiv det årstal du begyndte på din seneste BA, fx "2006")

7. Hvordan vurderer du din generelle arbejdsindsats på studiet? (sæt kun ét kryds)

Meget høj Høj $\quad \begin{gathered}\text { Hverken } \\ \text { højeller } \\ \text { lav }\end{gathered}$ Lav Meget lav


8. Hvordan vil du vurdere dit faglige niveau i forhold til andre på din årgang? (sæt kun ét kryds):
- I den bedste femtedel
- I den næstebedste femdel
- I den midterste femtedel
口 I den næstdårligste femtedel
I den dårligste femtedel

9. Hvor stort er omfanget af dit ugentlige Iønnede studiearbejde i dette semester? (sæt kun ét kryds)

Højest 5 timer

- Mere end 5 timer, højst 10 timer

- Mere end 10 timer, højst 15 timer

- Mere end 15 timer, højst 20 timer

a Mere end 20 timer

10. Hvilken karakter fik du ved den seneste eksamen på statskundskab? (sæt kun ét kryds)
口 02 eller derunder
口 4
ㄱ 7
10
ㅁ 12

11. Hvad er din mors højest gennemførte uddannelse? (sæt kun ét kryds)

Grundskole (fx 7.-10. klasse, realeksamen)

- Gymnasial uddannelse (almen gymnasium, HF, HH, HTX)

- Erhvervsfaglig uddannelse (fx fagudlært indenfor håndværk, handel el. kontor)

- Kort videregående uddannelse (fx social- og sundhedsassistent/-hjælper)

- Mellemlang videregående uddannelse eller BA ( $f x$ folkeskolelærer, pædagog, sygeplejerske)

- Lang videregående uddannelse eller forskeruddannelse (kandidatuddannelse, ph.d. el. lign.)

V Ved ikke

12. Hvad er din fars højest gennemførte uddannelse? (sæt kun ét kryds)

Grundskole (fx 7.-10. klasse, realeksamen)

- Gymnasial uddannelse (almen gymnasium, HF, HH, HTX)

Erhvervsfaglig uddannelse ( $\mathrm{fx}$ fagudlært indenfor håndværk, handel el. kontor)

- Kort videregående uddannelse ( $\mathrm{fx}$ social- og sundhedsassistent/-hjælper)

- Mellemlang videregående uddannelse eller BA ( $\mathrm{fx}$ folkeskolelærer, pædagog, sygeplejerske)

- Lang videregående uddannelse eller forskeruddannelse (kandidatuddannelse, ph.d. el. lign.)

Ved ikke

Tak for hjælpen! 
Bilag 2: Deskriptiv statistik for variable der indgår i analysen ${ }^{4}$

\begin{tabular}{lccccc}
\hline & Gns. & Std.dev. & Min & Max & N \\
\hline Afhængige variable & & & & & \\
Formidling (1) & 0.91 & 0.15 & 0.33 & 1 & 208 \\
Tilgængelighed (2) & 0.22 & 0.24 & 0 & 1 & 192 \\
Engagement (3) & 0.63 & 0.24 & 0 & 1 & 199 \\
Velstruktureret (4) & 0.67 & 0.21 & 0 & 1 & 202 \\
Fagligt overblik (5) & 0.65 & 0.24 & 0 & 1 & 197 \\
Venlig (6) & 0.28 & 0.22 & 0 & 1 & 193 \\
Inddragende (7) & 0.24 & 0.26 & 0 & 1 & 191 \\
Gruppearbejde (8) & 0.41 & 0.28 & 0 & 1 & 202 \\
Studenteroplæg (9) & 0.17 & 0.23 & 0 & 1 & 201 \\
Praktikere (10) & 0.54 & 0.30 & 0 & 1 & 204 \\
Forelæsning (11) & 0.90 & 0.23 & 0 & 1 & 207 \\
Perspektivering (12) & 0.33 & 0.47 & 0 & 1 & 208 \\
& & & & & \\
Uafhængige socio-demografiske variable & & & & & 209 \\
Alder & 0.12 & 0.12 & 0 & 1 & 209 \\
Studieanc. & 0.26 & 0.20 & 0 & 1 & 193 \\
Mors udd. & 0.78 & 0.27 & 0 & 1 & 1 \\
Fars udd. & 0.77 & 0.30 & 0 & & 197 \\
Uafhængige subjective variable & & & & & 209 \\
Selvv arb.indsats & & & & 1 & 1 \\
Mængde studiearb. & 0.69 & 0.20 & 0 & 0 & 1 \\
Selvv fagligt niv. & 0.38 & 0.33 & 0 & & \\
\hline
\end{tabular}

\footnotetext{
${ }^{4}$ For de 12 afhængige variable angiver værdien 1 den højeste mulige prioritet, mens 0 angiver den lavest mulige. For alder svarer værdien 0 til 20 år og 1 til 49 år. For studieanciennitet svarer værdien 0 til en anciennitet på 1 år, mens 1 svarer til 9 år. For mors uddannelse, fars uddannelse, selvvurderet arbejdsindsats, mængde studiearbejde og selvvurderet fagligt niveau angiver værdien 1 den højest mulige svarkategori (hhv. "lang videregående uddannelse eller forskeruddannelse", "lang videregående uddannelse eller forskeruddannelse", "meget høj", "Mere end 20 timer", "I den bedste femtedel"), jf. spørgeskemaet, mens værdien 0 angiver den lavest mulige svarkategori ("grundskole", "grundskole", "meget lav", "højest 5 timer", "I den dårligste femtedel").
} 


\section{Litteratur}

Biggs, J. \& Tang, C. (2007). Teaching for quality learning at university, New York: McGraw Hill.

Bloom, B., Hastings, J. T. \& Madaus, G. F. (1971). Handbook on formative and summative evaluation of student learning. New York: McGraw-Hill.

Brophys, J. E. (2010). Motivating students to learn, New York: Routledge.

Lassesen, B. \& Jensen, T. K. (2011a). Demographic and contextual predictors of student approaches to learn and in a large sample of Danish university students, working paper presented in B. Lassesen (2011): Student approach to learning. An empirical investigation of factors associated with student approach to learning. $\mathrm{PhD}$ thesis, submitted at the Department of Psychology and Behavioural Sciences at Aarhus University.

Lassesen, B. \& Jensen, T. K. (2011b). Motivational factors as predictors of student approach to learning, working paper presented in B. Lassesen (2011): Student approach to learning. An empirical investigation of factors associated with student approach to learning. PhD thesis, submitted at the Department of Psychology and Behavioural Sciences at Aarhus University.

Marton, F. \& Säljö, R. (1976). On qualitative differences in learning - I - Outcome and Process, British Journal of Educational Psychology, 46(1), 4-11.

Ramsden, P. (2003). Learning to teach in higher education, Abington, Oxon: Routledge.

Thomsen, J. P. (2012). Exploring the heterogeneity of class in higher education: Social and cultural differentiation in Danish university programmes, British Journal of Sociology of Education, 33(4), 565-585. 